\title{
Unpacking the politics of great power responsibility: Nationalist and Maoist China in international order-building
}

\author{
Beverley Loke
}

\begin{abstract}
Despite its prominence in the discourse of international politics, the concept of 'great power responsibility' remains largely unmapped in International Relations. Existing accounts tend to focus their analysis at a structural level and do not pay adequate attention to agency and processes of deliberation, negotiation and contestation. Drawing on constructivist insight to extend existing English School scholarship, this article unpacks great power responsibility as a socially constructed and negotiated concept. It develops a typology to further investigate the politics of great power responsibility and focuses specifically on four categories: the location, object, nature and rationale of responsibility (respectively, responsibility by whom, to whom, for what, and why). This conceptual framework is applied to China at two important international order-building junctures: institutional construction during World War II and institutional accommodation in the Cold War. In doing so, the article illuminates China's historical agency and uncovers the processes of both conflict and concordance that have shaped Chinese engagements with the question of great power responsibility.
\end{abstract}




\section{Introduction}

Great power heralds great responsibility. By virtue of their status and entitlements in international society, great powers have special responsibilities to provide leadership and maintain international order. Over the course of international history, the idea of great power responsibility has become common parlance in prescribing the foreign policy behaviour of great powers since they arguably have the most capacity to influence the direction of international order. Yet despite its prominence in the discourse of international politics, the concept of 'great power responsibility' remains relatively unmapped in International Relations (IR). In many respects, the concept is largely taken as an unproblematic given, with the politics surrounding great power responsibility often neglected. A deeper inquiry into the notion and assumptions of great power responsibility, however, reveals fundamental ambiguities on the conceptual debate on great power responsibility — what I refer to as the 'responsibility problématique'. Unpacking the concept of great power responsibility reveals significant ambiguity over what responsibility entails, how it is being defined and redefined in political discourses over time, who is engaged in this process and for what purposes. These issues are significant because they speak directly to questions of power and international order. As the manner in which great powers exercise their power and responsibilities carries more moral weight and directly influences international affairs, how they define and project, 
and the extent to which international society acquiesces to, the notion of responsibility relate directly to the ways in which the boundaries of society are constructed.

This opens up space for conceptual innovation and the article makes two conceptual moves in this regard. First, it takes as its starting point the need to problematise the concept of great power responsibility in IR. It argues that we need to unpack great power responsibility as a socially constructed and negotiated concept. In interrogating ideas of the 'social', however, this article seeks to highlight not only what is constructed, agreed and shared. Rather, it also involves examining what might be negotiated, resisted and contested, and how these ideas evolve over time. Most accounts of great power responsibility are situated in the English School. This article shares a similar starting point, but also draws on a constructivist approach to further advance a conceptual understanding of great power responsibility. Constructivism will be useful here because it seeks to illuminate how those dimensions of international life that are often taken as natural, given or embedded are inherently the product of agency and social construction (Hopf, 1998). Second, the article then establishes a typology through which we can examine the politics of great power responsibility. It focuses specifically on four categories - the location, object, nature and rationale of responsibility (respectively, responsibility by whom, to whom, for what, and why). By mapping out the concept in a more systematic manner, this article seeks to fill the conceptual gap in an understudied but widely used area. 
This conceptual inquiry is directed toward two important junctures in the context of China and international order-building. International order is understood here as a purposive pattern that sustains the primary goals of international society (Bull, 1977: 8). Order-building periods hence 'play a sort of constitutional function, providing a framework in which the subsequent flow of international relations takes place' (Ikenberry, 2011: 12) and, in that context, provide important sites to examine how China has negotiated the terms and institutions of international order. Given the current evolving reconfiguration of global power, many questions abound regarding the extent to which China will support, overthrow or reshape the existing international order. It is in this light that the discourse of 'responsible stakeholder' or 'responsible great power' has entered the global foreign policy lexicon as a constant reference point for China (Breslin, 2010; Schweller and Pu, 2011; Zoellick, 2005). This article nevertheless posits that there is a wider historical narrative to tell by historicising the question of responsibility in China's order-building endeavours. The two periods examined here are institutional construction during World War II (WWII) and institutional accommodation in the Cold War, specifically in the context of the United Nations (UN). The article illuminates China's historical agency as well as the politics surrounding its great power role and responsibility at that time. It further highlights the continuities and discontinuities in the location, object, nature and rationale of China's responsibility across the two periods. 
This article proceeds in four sections. It first situates great power responsibility within the broader IR theoretical literature. It underlines the important contribution the English School makes over realist accounts by introducing societal dimensions, but identifies the remaining gaps in English School theorising on great power responsibility. The abovementioned responsibility problématique will be refined here. This forms the basis for the second section, which draws on a constructivist approach to further unpack great power responsibility as a socially constructed and negotiated concept. A typology is also advanced here to investigate the politics of great power responsibility. The third and fourth sections respectively examine the two historical periods in the context of the established typology. They focus specifically on the underlying dynamics concerning China's great power membership, role and responsibility. The article concludes by underlining the broader conceptual and empirical implications.

\section{Great power responsibility in International Relations theory}

The ranking of powers and recognition of the significance of great powers are enduring features in IR theory. As Morgenthau (1973: 447) described, 'the preponderance of the great powers on the international scene is a fact'. There is a consensus that great powers are of fundamental importance because 'the axis around which world history and contemporary international relations turns is the concentrated resources and determinative behavior of the 
Great Powers, whether acting severally or together' (Nolan, 2004: 15). Emerging from this is the corresponding idea that those who have the greatest concentrations of power should shoulder greater responsibilities. The notion of great power responsibility nevertheless remains a heavily understudied concept in IR theory. Although most of the existing theoretical works generally agree on the idea of great power and great power responsibility, they struggle to comprehensively elucidate the complex social dynamics surrounding the concept of great power responsibility.

\section{Realist conceptualisations of great power responsibility}

For realists, great powers are distinguished first and foremost by their military capabilities in relation to others. A state becomes a great power when it is able to stage but not necessarily win a conventional war with the existing predominant power (Mearsheimer, 2001: 5). Yet while realists prioritise the concept of national power, they do not all necessarily entirely discount the notion of responsibility. In Theory of International Politics, Waltz (1979: 198) expressed that 'those of greatest capability take on special responsibilities'. Great powers are managers of the system performing system-wide responsibilities, albeit ones that are inherently driven by self-interest and geared toward the preservation of an international system that seeks to privilege their specific interests (Waltz, 1979: 198). Nevertheless, although Waltz does not deny that great power brings responsibilities, he does not refer to 
the great powers as forming or acting within an international society since he does not endorse the idea of international society (Brown, 2004: 11). Rather than through any societal element, the great powers will come to identify themselves with the system and adopt an instrumental conception of great power responsibility.

Classical realists may also be seen to weigh in on the debate, although they focus more on the notion of responsible power rather than on the idea of great power responsibility per se. A prudential ethic, of weighing options and making informed judgements regarding unintended consequences, is perceived to be the greatest virtue in guiding foreign policy (Harries, 2005). Political action is in essence thought to be a synthesis of Max Weber's 'ethic of ultimate ends' and 'ethic of responsibility', where the concept of responsible power subsumes both intentions and consequences, and places emphasis on judgement and accountability (Rosenthal, 1991: 42-45). In this regard, classical realists bring relevant insights on deliberation and choice in the constitution of responsible power.

Most realists thus acknowledge that great powers should bear responsibilities commensurate with their power status. This is so even though classical realists seek to privilege the notion of prudence and structural realists tend to explain this logic through an instrumental 'stake in the system' argument. Realism's affiliation with responsibility nevertheless remains a rather ambiguous one. Claude Jr (1986: 721) captured this relationship succinctly when he observed that realists 'are comfortable neither in repudiating it nor in admitting it to their theory of international behavior. They...tend to treat responsibility as a 
kind of intellectual loose end, kept on hand but never woven into the fabric of systematic thought about international relations'.

The English School's conceptualisations of great power responsibility

Should Britain and France seek the role of great powers, accepting the risks and sacrifices of such a role along with its rewards, or should they retire to join Holland and Sweden in enjoying in the full, solid comforts of international suburbia? (Bull, 1964: 20-21)

The English School engineers an important shift from realism by introducing a social element into conceptualisations of great power responsibility. Admittedly there are overlaps between the English School and realism's primarily materialist conceptualisation of a great power. The privileging of material power and the notion that the differentiation of responsibility stems from material inequality also find acceptance in the English School (Wight, 1978: 5152; Zimmern, 1939: 82). Unlike realists, however, proponents of the English School highlight the idea of a social role. They argue that a great power is distinguished by both its material capabilities and intersubjective understandings of its social role. As Vincent (1990: 62-63) argued, the great powers 'were burdened by responsibility as much as benefited by power, and theirs was a role that had to be played'. Bull (1977: 199-200) similarly observed that '[t]he contribution of the great powers to international order derives from the sheer facts of 
inequality of power as between the states that make up the international system...But over and above this contribution,... they may play a role in the promotion of international order by pursuing policies that work for it rather than against it'.

This other defining quality of a great power — the intersubjective social role - moves beyond the traditional realist paradigm to also include the social purposes for which power is wielded. Material power is important but because states operate in a social world, there is a need to examine the purposes to which that power is exercised through claims, projections and the shouldering or shirking of responsibility. It is therefore the role and responsibility of great power, along with the moral significance and consequences of that power for world affairs, that is crucial (Jackson, 2004: 62). Perhaps one of the first references to the idea of great power responsibility may be found in the work of Zimmern (1939: 83-84):

[T] he problem of international politics is not the elimination of the conception of Power, but its transformation-we may even say its sublimation-through the influence of the notion of moral responsibility... If such a development should reach its completion, some states would still be found stronger than others - for equality is not of this world-but there would no longer be Great Powers. There would only be Great Responsibles.

In this regard, great powers are charged with an ethic of responsibility and are compelled to fulfil their international obligations. Naturally, all states have a responsibility to defend and promote their national interests. The notion of interests remain ever present because states 
are, after all, 'strategic actors embedded in a socially constructed environment' (Hurd, 2005: 497). However, the international society approach of the English School envisages the great powers as embodying an enlightened self-interest that takes into account the broader interests of the other members of international society and works toward maintaining international order. The social construction of great power thus encompasses the recognition of status, rights and responsibilities.

The most visible treatment of great power responsibility in the English School tradition has been that of Bull's (1977: 196), who wrote that great powers are 'recognised by others to have, and conceived by their own leaders and peoples to have, certain special rights and duties'. This statement captures the dual, albeit interrelated, conceptions of great power prerogative and obligation but, more crucially, introduces the societal element of the concept — that these rights and duties are recognised by both self and others. For Bull (1977: 200-220), great power responsibility toward the promotion of international order involved two key elements: (1) the management of relations between the great powers themselves; and (2) the orchestration of international affairs between the great powers as an elite directorate and the rest of international society. In this context, the role and obligations of great powers may be conceptualised as encompassing a dualistic nature: a 'horizontal concert' comprising the management of relations between great power peers and a 'vertical hierarchy' reflecting the duties of the great powers as a collective to the rest of international society (Clark, 2009: 220). The former is particularly important because 'if reciprocity is fundamental to viable 
special responsibilities, so is the existence of a peer constituency from which the responsibilities are partly derived, and to which they are in part owed' (Bukovansky et al., 2012: 45).

The fundamental point, therefore, in such a conceptualisation of great power, is that the attribution of great power status is highly contingent on the extent to which the exercise of its power and its contribution to international order is deemed legitimate and is accepted by the other members of international society (Bull, 1977: 221). In other words, the relationship between great power privilege on the one hand, and great power obligation on the other, is largely transactional in nature and may be contested if a great power is not successfully performing its functional managerial role. The concept of great power responsibility thus seeks to reconcile the seeming tension between the principle of equality (that all states are formally equal) and the notions of differentiation and hierarchy (states can be unequal in status) (Simpson, 2001). Particularly because the conferred status is a political act of recognition informed by social underpinnings, it embodies normative requirements of responsibility, legitimacy and authority.

Two aspects of normativity are worth mentioning here. First, the possession of preponderant power does not guarantee responsible behaviour, a point Bull himself often made. After outlining the roles and responsibilities of great powers in The Anarchical Society, he wrote that it 'is not a description of what great powers actually do. It is rather a statement of the roles they can, and sometimes do, play that sustain international order' (Bull, 1977: 
200-201). In other words, international order is upheld through 'the intermittent assumption by the great powers of responsibility for the management of international politics' (Bull, 1968: 3) [emphasis added]. Great power responsibility is hence a normative expectation of state conduct. Although great powers are recognised to have responsibilities, they may not necessarily fulfil them.

Second, the scope of great power managerial responsibilities would depend on the normative ambitions of international society. To this end, the English School has traditionally been distilled into either the pluralist or solidarist camp. Pluralists are generally understood to privilege the state and conceptions of order, where order is understood in minimalist terms as the conditions for coexistence between states. Solidarists, on the other hand, envisage a greater normative purpose for international society, emphasising notions of justice and often prioritising individuals over states (Bull, 1966; Wheeler, 1992). Many English School theorists have nevertheless argued that it is not a matter of order versus justice, but rather of reconciling order and justice as part of an inherently normative exercise (Hurrell, 2007). As Bull (1983: 227) pointed out in his later writings, 'order in international relations is best preserved by meeting demands for justice, and that justice is best realized in a context of order'. Pluralism and solidarism are therefore best positioned as two concepts on opposite ends of a spectrum, representing degrees of difference, rather than as mutually exclusive and contradictory positions (Buzan, 2004a: 49). This allows us, in the context of this article, to 
understand Nationalist and Maoist China's demands for justice and the normative scope of its responsibility claims.

\section{The responsibility problématique}

By introducing the societal element, the English School advances our understandings from realist accounts and offers a good starting point for a conceptual study of great power responsibility. This social dimension is important, indeed crucial, to an understanding of responsibility and lends legitimacy to the exercise of power. The English School's analytical focus nevertheless often remains directed at the structural level and does not go far enough in uncovering agency and interrogating the underlying subjective-intersubjective dynamics with regards to great power responsibility. Much of the existing conceptual debate on great power responsibility remains plagued by a 'responsibility problématique' that comprises three interrelated components.

The first is that the English School is very proficient in providing conceptual typologies but is often less so in explaining and applying these to the underlying dynamics

of international politics (Dunne, 2008: 281; Finnemore, 2001: 509). International society, as defined by Bull (1977: 13), exists when a group of states are 'conscious of certain common interests and common values' and conceive themselves to be bound by a common set of rules and institutions. It nevertheless remains ambiguous what exactly is meant by 'certain 
common' interests and values. Further, it begs the question of whether we are missing the opportunity to explore the underlying deliberations that great powers may make with respect to their responsibilities and examine how understandings of great power responsibility have themselves shifted and evolved over time. This conceptual ambiguity is further highlighted given the expanded notion of society that currently exists today. The current diverse make up of international society and the norms that constitute that society may very well mean that what responsibility entails might actually be less consensual.

Second is a neglect of the subjective-intersubjective interplay. Fundamental ambiguities arise because while the idea of responsibility may be intersubjective at an abstract level, it remains heavily contested at a definitional level and lends itself to myriad interpretations about what it truly means to be 'responsible'. It is one thing to claim that the 'sovereign state is the foundation of responsibility in world affairs' (Jackson, 2004: 58), as this is largely undisputed. However, it is entirely different to claim that a state's domestic political system, whether it be under the direction of a constitutional leader or an authoritarian dictator, 'cannot affect the question of international responsibility because that is settled by the prior existence of the sovereign state on whose behalf such individuals are considered to act' (Jackson, 2004: 58). This line of thinking assumes the existence of explicit consensual knowledge and shared understandings across different state leaders of what their international responsibilities are, or should be, when conceptualisations of responsibilities could in fact differ rather significantly. 
Finally, and underlying the previous two points, there is inadequate attention to negotiation and contestation in international society. It remains unclear why disagreements and struggles over responsibility have been given less space in the literature and what such contestation can in fact reveal about the basis, boundaries and constitution of international society. ${ }^{1}$ As mentioned above, Bull places emphasis on the recognition of a social role both by the state concerned and by other members of international society. This twofold aspectof self-perception and social acceptance of special rights and responsibilities-is fundamental to his definition of a great power. Such an understanding nevertheless assumes there must always be some degree of normative alignment between what is self-claimed and what is ascribed by others, when in reality this relationship is much more tenuous. Rather than simply examining what is shared and agreed, we need then to also focus our attention on the resistance, negotiation and contestation of responsibility that occur within international society. Put simply, how can we better understand the politics of great power responsibility?

\section{Unpacking great power responsibility as a socially constructed and negotiated concept}

It is posited here that we need to problematise the idea of great power responsibility in order to gain a more comprehensive understanding of the concept. This article therefore argues that there is a need to unpack great power responsibility as a socially constructed and negotiated 
concept. Rather than believing that we can discover an 'objective truth' about what it means to be responsible, we should instead think about responsibility both socially and functionally because 'concepts and principles of responsibility do not exist (purely) for their own sake but as part of a complex set of practices of taking responsibility and holding responsible' (Cane, 2002: 281). This means that we need to investigate not only the ways in which individuals and states may be held accountable but more significantly, to interrogate the socially constructed and embedded nature of responsible agency (Hoover, 2012). Understandings of great power responsibility must thus be examined not simply in subjective terms (as something existing from an agent's perspective) or in intersubjective terms (as bound up in shared social practices), but as an interaction between the two.

The notion of responsibility is both prescriptive (what actors should do) and evaluative (a basis upon which evaluations can be made). The former is future-oriented and establishes obligations relating to roles and tasks, while the latter looks to the past and involves conceptions of accountability and answerability (Erskine, 2003: 8). Both are nevertheless inherently related and it is on this basis that projections, expectations and demands can be made by international society. Judgements of responsibility are made taking into account our configuration of social roles, conceptions of communal boundaries and the distribution of power in society (Smiley, 1992: 13). Such judgements change over time 'not only because of new causal discoveries, but because we as a community have come to alter our expectations of particular individuals on the basis of shifts in social and political power' 
(Smiley, 1992: 13). Members of international society have as much say in projecting, ascribing and allocating responsibilities to the great powers, and must acquiesce to a great power's claimed responsibilities in order for them to be legitimate. Responsibility is thus 'social' in the sense that 'the allocation of responsibilities shapes the contours of social orders - constituting role identities, affecting the distribution of legitimate social powers and conditioning the prevailing moral grammar' (Bukovansky et al., 2012: 52). The idea of responsibility therefore only makes sense if we examine it in the context of norms of appropriate conduct as well as societal expectations and projections-even if, as will be discussed below, these may be constantly evolving, negotiated or contested.

In other words, the politics of ascribing and assigning responsibility is underpinned by the social function of establishing and maintaining social norms, and it is through our participation in social practices that we assume responsibilities and are constructed as responsible agents (Frost, 2003; Hoover, 2012). While great power norm projection and enforcement are important (Fordham and Asal, 2007; de Nevers, 2007), so is how that power is received - a recognition that power is inherently nested in social structures. Indeed, ' $[\mathrm{t}] \mathrm{o}$ hold an agent responsible is to insist that her behaviour takes social obligations into account, but being held to account also mould individuals and collective actors into agents capable of changing their behaviour in specific ways' (Hoover, 2012: 254). When we project responsibility onto others, we import wider social expectations into our attributions and judgements. 
Notions of great power responsibility are nevertheless influenced by an actor's identity and orientation toward a particular international order or visions of alternative orders, and are best understood as situated, contextualised and evolving. Responsibility and international order are thus not static or politically neutral concepts, but rather reflect an interactive and negotiated process between actors who project responsibility claims, and those who receive and respond. This relationship between responsibility and order is especially useful when thinking about status quo and revisionist powers. Whilst the former are content with the existing ordering principles of international society and seek selfpreservation of their positions in that society, revisionist states 'value what they covet more than what they currently possess' (Schweller, 1994: 105). The prevailing order is viewed as unjust and illegitimate, and their primary revisionist goals are to destabilise the system and advance their prestige.

It is therefore important to examine the processes of deliberation, negotiation and contestation within the discourses and practices of responsibility. Responsibilities may be claimed and shouldered, but they may just as easily be deflected, denied, shirked and negotiated in response to the projections of others. As mentioned earlier, Bull's conception of international society places emphasis on the recognition of established rules and norms; society is constituted by accepted notions of what is recognised to be shared and common. Yet, significantly, a notion of 'society' as that which is all agreed upon and established appears rather static. Disagreements and conflicts are, in fact, just as much evidence of a 
society and 'the social' as the stable conceptions. In this regard, struggles over understandings of responsibility can tell us as much about international society and the constitution of social orders as seemingly established and intersubjective notions can (Bukovansky et al., 2012: 61-64). Examining negotiation and struggle thus provides crucial insights into how international society and international order are being defined and redefined.

Intersubjectivity is the product of, and remains subject to, constant deliberation and negotiation. International society undergoes processes of construction and reconstruction to reach some degree of consensus, and it is that intersubjectivity that then gives meaning to international practices, even if it might remain under constant reinterpretation. As Wendt (1999: 340) reminds us, 'we should not forget that what we take to be given is in fact a process that has simply been sufficiently stabilized by internal and external structures that it appears given'. We should therefore pay attention to how intersubjectivity is achieved in the first place, how subjective understandings interplay with intersubjective ones and how intersubjectivity remains a site of constant struggle and contestation. This allows us to view international society as a process that is continually evolving through subjective and intersubjective interaction, rather than as a categorical given (Qin, 2010). It is in this context that the next subsection seeks to further unpack the negotiated and contested aspects of great power responsibility.

The location, object, nature and rationale of responsibility 
The notion of responsibility is undoubtedly a relational one-it is a social relationship that entails a responsibility to someone for something. A comprehensive inquiry into the politics of great power responsibility, however, must go further to address four fundamental sets of referents: responsibility by whom, to whom, for what and why-or what is respectively labelled as the location, object, nature and rationale of responsibility. ${ }^{2}$

Location. Even if we accept the position that greater responsibility resides with the great powers, a distinction should be made as to whether this responsibility is self-claimed by the great powers or assigned and projected by others. This raises two interrelated issues. The first relates directly to who determines which actors have responsibilities and how these responsibilities are allocated and distributed. If we are indeed to understand great power duties from a social perspective, then it is important to address the issue of audience. Who are the relevant actors or groups of actors who recognise, legitimate and establish boundaries of what is appropriate? Here, we may not be referring to a single 'community of recognition' (Clark and Reus-Smit, 2013: 43) but rather different and multiple clusters of recognition groups, thus highlighting the potential contestation that can occur in the acts of ascribing and legitimating. Second, what happens when there are disconnects between what is self-claimed and what is ascribed by others (Buzan, 2004b: 61)? This can occur in either of two ways: when self-perception exists but there is contested social acceptance; or alternatively, when there is social ascription but there exists contestation within the state in question as to its self- 
conception and role. There may hence be resistance or contestation among the great powers as to what their responsibilities should be, or among members of international society as to which actors should be accorded the rights and responsibilities that are associated with great power status. Answering the question 'responsibility by whom' therefore requires that we address the politics of claiming and ascribing responsibility, and of how subjective claims and social ascription are produced, received and negotiated.

Object. The question 'responsibility to whom' is explicitly concerned with to whom, or to what, these great power responsibilities are intended. Are obligations owed to international society in general terms, or more specifically to certain distinct groups? In addition, as with the category above, when we make reference to a great power having responsibilities to something or to certain actors, are these self-claimed or projected by others? This involves examining where great power responsibilities should be directed, both from the perspective of the great power and the various communities of recognition.

Nature. Seeking answers to the question 'responsibility for what' requires a focus on the scope and nature of a great power's responsibilities. This may involve examining the different types of domestic and international responsibilities that are required of a great power, how a great power balances between them and the choices that are made between conflicting obligations. There may clearly be disagreements over the scope and nature of responsibility, between what is self-ascribed and projected by others, and it may often be the case of a great power denying, resisting or shirking certain obligations. 
Rationale. Why should the great powers shoulder greater responsibilities? At first glance, this might seem like a rather obvious question. We expect this because the great powers are widely assumed to be the actors with the greatest agential capacity to influence international affairs. Yet, as mentioned above, possessing great power does not automatically translate into responsible behaviour. Moreover, it depends as much on who defines what responsibility means and on what basis judgements of 'responsible' or 'irresponsible' are made. One may rightly ask where this sense of responsibility originates, who is defining what these international responsibilities are and how states and their leaders come to conceive, rationalise or internalise these international obligations. Indeed, the framing of responsibility claims is often attributed to historical or identity-related factors.

Interrogating great power responsibility as a socially constructed and negotiated concept requires that we further uncover the politics surrounding the location, object, nature and rationale of responsibility. What the above typology does is capture the complex relationships states have with themselves and others. Debates about great power responsibility thus need to be placed within the broader context of meanings and interpretations that different actors attach to the concept, and how these are then negotiated and reconceptualised. It is this subjective-intersubjective interplay that gives the concept of great power responsibility its dynamic characteristic. The typology is therefore a useful analytical tool to unpack the politics of great power responsibility in further detail, and will now be applied to China and order-building during WWII and the Cold War. 


\section{Nationalist China and institutional construction during WWII}

Ravaged by another world war, this order-building period focused on establishing the terms for peace and cooperation through the institutionalisation of great power managerialism (Morris, 2013). How the great powers debated and projected ideas about their roles and responsibilities, however, have been given less prominence in the literature. This is especially so in the case of China, with the vast majority of scholarship emphasising the role of the Big Three (Great Britain, the Soviet Union and the US) and tending to neglect China's wartime

role in negotiating a post-war order. ${ }^{4}$ By unpacking notions of great power responsibility along the lines of the established typology, this section highlights Chinese agency and ideas of great power responsibility, while also revealing the contested intersubjective boundaries and social acceptance of its status.

Location: Responsibility by whom

In many ways, the US was the primary actor conferring great power prestige and responsibilities onto China. Largely predicated on the assumption that China had a prominent post-war role to play, and one that would ultimately serve US interests, President Franklin Roosevelt believed it would be advantageous to elevate China's international status. A post- 
war collective security system designed to construct and maintain peace was to be centred on the great powers, and these ideas found expression in his concept of the Four Policemen (Davis, 1943: 109; Kimball, 2008: 99). China would emerge as a guardian of regional order to check Japanese power, serve as a political counterweight to the Soviet Union, limit revolutionary upsurges in Asia and be an overall stabilising force in the Far Eastern balance of power (Hull, 1948: 1587; Range, 1959: 178). In this light, Roosevelt perceived China 'as being an order-giving and order-providing society, a society that was so stable itself that it had order to export' (Arthur Waldron, 2010, interview) [emphasis added].

American sponsorship of China's great power club membership was warmly received by the Chinese. Undoubtedly, the situation in China was far from stable, with a Nationalist government confronted with challenges from the Chinese communists and the Japanese. Its former status nevertheless cast a long shadow on its great power consciousness. In the initial stages of post-war planning, China therefore did not really have to struggle in reconciling its responsibility claims with the projections by the Roosevelt administration. American attributions of great power status intersected with Chinese conceptualisations and reinforced their subjective understandings of self, role and responsibility. The discourse of responsibility was embraced by the Nationalist leadership and used as a rallying call to the domestic public to contribute more substantially to international peace, stability and order. At least in rhetoric, the Nationalist leader claimed China to hold special responsibilities in international society. 
The notion that China should be assigned special managerial responsibilities for regional and international order was nevertheless resisted and contested at varying degrees by others. Even though Washington perceived China as the bastion of regional stability and drew it into the Allied inner circle, its great power peers, Great Britain and the Soviet Union, viewed China at best as peripheral, and at worst as unworthy. Winston Churchill (cited in Dallek, 1979: 389), for instance, remarked that '[i]t is quite untrue to say that China is a world power equal to Britain, the U.S., or Russia'. This raises interesting insights into whose perspectives matter the most in establishing the boundaries of inclusion and exclusion, and in locating responsibility in international relations. The US was obviously more willing to grant China greater respect and inclusion than its peers in the early to mid-1940s. Despite resistance from its peers, the US managed to secure China's participation at a series of key international wartime conferences dealing with strategic wartime and post-war planning.

\section{Object: Responsibility to whom}

The object of Nationalist China's responsibility was largely universal in application, with responsibility directed inwards to the self and outwards to the region and broader international society. Two statements by Generalissimo Chiang Kai-shek were particularly telling. In a 1940 address, he remarked that the Chinese public "must realize the nature of our responsibility which extends to the fate of East Asia and the world. It is a responsibility 
not to be shirked but to be upheld with a courage equal to the immense and noble enterprise" (Chiang 1940: 213). And at the closing ceremony of the Third People's Political Council, Chiang (1942: 308-309) proclaimed:

[W]e must shoulder the responsibilities this age has laid upon us. The nation is responsible not only for its own interests but also for those of the world... after the war we must be prepared... to do all that is required in collaborating with those nations to recreate world order.

Such statements strongly highlighted an enlightened notion of international responsibilityan obligation beyond the self to also include the other members of international society. Within this, there was a particular focus on a responsibility to Asia which, as will be discussed shortly, stemmed from China's historical legacy in the region. With respect to the US, the key actor ascribing great power responsibilities onto China, both countries converged on the object of responsibility and to whom responsibilities are owed. They were coming to terms with their great power status, both real and perceived, but this did not result in contending visions of a post-war order. Thus to a large extent, Chongqing and Washington 'held similar conceptions of responsibility in terms of policing the world' (Zhang Qingmin, 2011, interview).

Nature: Responsibility for what 
One may in fact posit that the Chinese were actually more ambitious and idealistic in their ideas concerning the nature and scope of great power responsibility. They approached international wartime conferences such as the 1944 Dumbarton Oaks conference with a more extensive list of issues and sought to ascribe greater responsibility onto the great powers in the UN Security Council than its peers were prepared to deliberate or put into practice. From Chiang's perspective, China's post-war great power responsibilities were to ensure greater equity in the international order, support the independence movement in Asia and be a spokesperson for weak nations (Wang Lixin, 2011, interview). The Chinese proposal at Dumbarton Oaks therefore called for greater attention to racial equality, justice and international law, and to an extent the principles embodied in the proposal reflected 'China's desire to create an organization with teeth in it' (Hilderbrand, 1990: 236). ${ }^{5}$ During discussions, the Chinese delegation proved especially concerned with the Council voting procedure and Soviet insistence on great power unanimity when a permanent member was involved in a dispute. They sought to incorporate a supplementary statement addressing three key issues: the principles of justice and international law; the codification of international law; and cultural cooperation. Ensuring that dispute decisions made by the new international body would be guided by law and justice, for instance, was necessary to prevent the organisation from degenerating into a vehicle for power politics. By insisting on its inclusion, they believed that China had injected a normative basis to this order-building project, 
delivering what Under Secretary of State Edward Stettinius Jr later noted as 'a number of interesting and helpful suggestions' (FRUS, 1944: 851-856, 864, 871; Craft, 2004: 181). The Chinese thus surpassed expectations by contributing valuable ideas to the institutional design and planning for a post-war organisation (Hilderbrand, 1990: 243).

China was nevertheless later criticised by an American government official for not having contributed more to the Dumbarton Oaks talks despite having a 'bold and imaginative plan' (cited in Craft, 2004: 192). On paper, the Chinese proposal called for establishing a strong international body that would have the great powers shoulder greater responsibility while at the same time ensuring the support of the small powers (Craft, 2004: 192). Given the realities that China faced at that time, however, these high ideals could not be fulfilled for two key reasons. First, both Chiang and his diplomat Wellington Koo did not wish to push for the Chinese position at the expense of compromising its international status. Second, Dumbarton Oaks did not offer the Chinese delegation much space to manoeuvre and negotiate its position. Operating under such constraints, it was hardly surprising that accommodation and cooperation became the guiding framework of their approach to the Dumbarton Oaks Conference. On balance, however, the conventional assumption that China remained a passive participant in the negotiations of great power roles and responsibilities leading to the UN Charter is largely misguided. We can observe that there was much more agency on the part of the Chinese, who viewed their country as a great power worthy of articulating notions of great power responsibility. Even though China had to eventually 
streamline the scope and nature of its responsibility claims to align with its great power peers, understanding such ideational agency allows us to reinterpret this period as one in which China was actively seeking to be recognised as a responsible great power (Mitter, 2013: 5).

Rationale and justification of responsibility

China's great power identity and responsible agency were framed along the lines of its culture, civilisation and rightful position in Asia. These internal sources of responsibility were shaped by two key historical experiences. The first emerged out of the traditional Chinese world order, characterised by its own set of organising principles such as the superiority of Chinese culture, rituals of power in the form of tributary relations and the moral precepts of the Chinese emperor. As the Middle Kingdom in this hierarchical Sinocentric system and hence responsible for the maintenance of order, the concepts of rights and duties were not unfamiliar to China. The collapse of this order through its subjugation by the Western international system in the nineteenth century was therefore particularly traumatic for China (Zhang, 2001). Second, World War I and the Paris Peace Conference had highlighted a sea change in China's self-identity and its place in international society. This was a particularly revealing period about the enterprise of constructing a new national consciousness and China's commitment to internationalisation (Xu, 2005). Having to renegotiate its sense of self within the European international society, Western practices were gradually adopted and 
the language of responsibility was used to construct China as a civilised nation in this new Western order.

Taken together, these historical experiences helped to locate Nationalist China's responsibility claims and justify the object of responsibility extending to its immediate region and beyond. Responsibility in this order-building period was thus rationalised through an appreciation of China's moral and cultural superiority, and from Chiang's objective of restoring a China-centred post-war order in Asia (Van De Ven, 2015: 226). In a chapter of China's Destiny, Chiang (1947: 232) wrote 'it is from a sense of duty and responsibility, not from a desire to acquire privileges and material gains, that China wishes to establish herself and be strong'. He continued that '[a]n independent and strong China means a stabilized Asia, and freedom for Asiatic peoples and equality for Asiatic states will be a guarantee of a lasting world peace'. As mentioned earlier, Chiang emphasised in his public speeches the importance of securing independence and equality with a corresponding duty to fulfil the additional responsibilities placed upon it. The language of responsibility sought to justify national reconstruction and a greater international role. This universal application of responsibility in turn helped to legitimise its standing in international society. As one of the permanent members in the UN Security Council, Nationalist China secured a seat in the great power club that institutionalised managerial responsibilities for the maintenance of international order. The terms of this grand compact would, however, be renegotiated in the Cold War. 


\section{Maoist China and institutional accommodation in the Cold War}

The question of Chinese representation plagued the UN for over two decades, with the Nationalist and Communist governments both claiming the right to represent China in the international body. The vote on 25 October 1971 was thus a historic reversal that welcomed the People's Republic of China (PRC) into the international community. It reflected, and reaffirmed, the changing nature of international relations and ongoing reconfigurations in the international system. Although the structuring principles of international order revolved around the balance of power and spheres of influence, this section explores a complementary narrative concerning the role and responsibility of great power in relation to the PRC.

Location: Responsibility by whom

The Chinese Communist Party (CCP) certainly conceptualised and projected China as a great power with special responsibilities. Premier Zhou Enlai declared that 'China is a newly risen nation. We know that a newly risen nation, especially one which is a great power, often cannot be fully understood by other countries within a short period of time, and frequently arouses apprehension' (Chou, 1956: 17) [emphasis added]. From the very outset, the desire to gain UN admission was a key objective in the conduct of Beijing's foreign policy (Weng, 
1966). ${ }^{6}$ In a speech at the UN Security Council on 28 November 1950, Wu Hsiu-chuan (1950:

5-6) stated:

I would like to remind you that so long as the United Nations persists in denying admittance to a permanent member of the Security Council who represents 475 million people, it cannot make lawful decisions on any major issues or solve any major problems, particularly those which concern Asia. Indeed, without the participation of the lawful delegates of the People's Republic of China, representing 475 million people, the United Nations cannot in practice be worthy of its name. Without the participation of the lawful delegates of the People's Republic of China, the Chinese people have no reason to recognise any resolutions or decisions of the United Nations. $^{7}$

This statement was significant in revealing three important positions of the Communist leadership. First, Beijing undeniably perceived itself as a power worthy of Security Council membership and envisaged a role in contributing to regional and global challenges. Second, it implied that the international body would not be able to legitimately function and effectively solve global challenges as long as the PRC remained excluded. Third, until and unless a transfer of the UN seat occurred, Beijing would continue to deny UN jurisdiction and authority.

The idea that great power status and responsibility should be ascribed to the PRC was nevertheless resisted at varying degrees by international society, and particularly contested by the US. This resistance stemmed from the perception that the PRC upheld a conception 
of great power responsibility that significantly diverged from dominant notions in international society. From Washington's perspective, UN admission would increase Beijing's prestige, enhance the global communist movement and threaten vested US interests. For the most part of the 1950s and 1960s, Washington therefore invested significant diplomatic capital to enlist international support for opposing PRC membership in the UN. This was no doubt an interesting reversal from the previous section focusing on the earlymid 1940s. Whilst Washington had then campaigned for allied support in recognising Nationalist China's inclusion in international society not simply as an equal and legitimate member, but as a great power, this period witnessed much of the reverse. The US was now the key actor contesting Communist China's inclusion in international society as a great power with managerial responsibilities.

Although there was initial substantial international support for America's position, over time the international body nevertheless came to be viewed as an ideal platform to condition Chinese behaviour more in keeping with dominant understandings of great power responsibility. Much of this growing support for Chinese entry was driven by the increasing number of developing countries that had established diplomatic ties with the PRC and had come to acknowledge, particularly after China's successful 1964 atomic testing, that it was a great power.

Yet significantly, the communities of recognition seeking to ascribe great power status and responsibility to the PRC were not limited to the developing world. Despite an 
orchestrated US effort to alienate the PRC, some of America's closest allies believed that Beijing should be drawn into the full range of international interactions and be assigned great power managerial responsibilities. London, for instance, believed that a policy of engagement and conciliation toward Beijing would be more beneficial than one of containment (Kaufman, 2000). When Canada proposed in 1966 to seat the PRC in the Security Council but to leave the Nationalists in the General Assembly, Washington expressed its strong displeasure. In a personal letter to Canadian Prime Minister Lester Pearson, Secretary of State Dean Rusk wrote, 'I need not underscore the seriousness of such a split between our two nations' (cited in Foot, 1995: 44). This reflected an emerging disconnect between Washington and its allies on their respective China policies. America's allies felt that it was unrealistic for international society to attempt to solve global challenges without its participation, with many acknowledging that it was 'a vital requirement of international order that a system of great power understanding be devised in which she can take part' (Bull, 1973: 8).

\section{Object: Responsibility to whom}

Like Nationalist China, Maoist China conceived for itself a special role and accorded itself special responsibilities in a social and normative setting, directed inwards toward the self and outwards to the world. As a revisionist power, however, the object to which international 
responsibilities should be directed was fundamentally different. Responsibility was cast in anti-imperial terms and owed specifically to the Third World. Mao was a transformative figure: his goal was not just to manage, but to reshape international relations. China's foreign policy was thus grounded in a discourse of revolutionary struggle, aimed at creating a common solidarity with Third World nations, and with China positioned to play an important role as the voice of developing states.

It is in this light that the domestic-international nexus is crucial for understanding the Maoist image of world order. As Chen (2001: 15) articulates, despite the tendency toward militancy, the pursuit of centrality rather than dominance was the fundamental goal of Chinese foreign policy, and was one intrinsically linked to domestic objectives:

While Mao and his comrades were never shy about using force in pursuing China's foreign policy goals, what they hoped to achieve was not the expansion of China's political and military control of foreign territory or resources - which was, for Mao and his comrades, too inferior an aim — but, rather, the spread of their influence to other 'hearts and minds' around the world. Mao fully understood that only when China's superior moral position in the world had been recognized by other peoples would the consolidation of his continuous revolution's momentum at home be assured.

Undoubtedly, China's entry into the UN represented a better reflection of geopolitical realities and the balance of power. It symbolised a victory in the struggle for justice, equality 
and against entrenched privilege. It also introduced concrete structural change and accorded greater weight to the Third World. With its admission to the international body, China acquired a new platform to promote its anti-hegemonic policies and speak for this part of international society.

Nature: Responsibility for What

Throughout the Maoist period, the Chinese understanding of responsibility was grounded in notions of fairness, equality and justice. The method of achieving this, however, was through revolution and armed struggle against the dominant forces in the system. For Mao, 'China was the centre of world revolution and it had the responsibility to export revolution to the rest of the world' (Zhang Xiaoming, 2011, interview). He claimed China was the vanguard of the Third World, reaching out to developing nations with a common historical experience of colonialism, and promoted a strict enforcement of state sovereignty to rigidly oppose any form of First World interference (Van Ness, 1993: 205). As the self-proclaimed leader of oppressed nations, China's great power responsibility was hence to pursue a revolutionary notion of justice, struggle against hegemonism and radically transform the existing Westerndominated international order. Mao proposed a Chinese version of socialist internationalism that attached great importance to 'world revolution' and expressed China's international 
obligation as supporting global anti-imperialist and anti-capitalist revolutionary movements (Chen, 2005: 43-44).

The nature and scope of China's responsibility was thus fundamentally at odds with the US, whose conception of responsibility was to contain the spread of communism. From America's perspective, China was clearly not assuming great power responsibilities in line with intersubjective understandings. Granting Communist China UN membership would only offer Beijing an additional platform to project its subjective interpretations of great power responsibility, which Washington viewed as inherently dangerous and destabilising to international order. In that context, both China and the US held firm conceptualisations of great power responsibility, but the content of that responsibility was inherently different. This highlights very clearly the varied and constructed meanings of responsibility: what responsibility entails depends very much on who is defining and determining its meaning. Whilst many in international society perceived China as an irresponsible and revisionist power seeking to overthrow the system, struggling against the dominant forces in an unjust order was precisely what Beijing conceptualised as its responsibility.

These themes of anti-imperialism and revisionism were emphasised in an important first speech by the PRC delegation to the $26^{\text {th }}$ session of the General Assembly on 15 November 1971. The delegation chairman, Chiao Kuan-hua, remarked that China's resolute opposition to, and support for struggles against, imperialist oppression and aggression was consistent with the spirit of the UN Charter (Peking Review, 1971: 9). This basic position 
was reiterated by Huang Hua when he made his debut as Beijing's permanent representative to the Security Council on 23 November (UN SC, 1971: 9). In these first member speeches to the Assembly and Council, therefore, China outlined the nature of its great power responsibilities in the UN. The PRC made a clear distinction between its self-conception as a rightful great power championing the just cause of the oppressed, and the hegemonism of the superpowers. In other words, Beijing sought to set itself apart through its subjective conceptualisations and projections concerning the nature of its responsibilities. In the years immediately following its UN admission, Beijing continued conceiving of its responsibilities as oriented toward fighting against Soviet and American imperialism. UN entry did not lead to any discernable changes in its rhetoric or its diplomatic objectives. It did not significantly alter Beijing's responsibility claims because it still valued its self-appointed responsibilities to advancing the causes of developing states (Wang Lixin, 2011; Zhu Feng, 2011, both interviews).

Rationale and justification of responsibility

Winning the UN seat held important implications for China's notions of great power responsibility. There is nevertheless an important conceptual distinction to make here. China certainly identified itself as a great power and wanted to be recognised as such — indeed, it spent over two decades trying to seek this recognition from international society. As Kim 
(1979: 87-88) wrote of Mao, '[h]istorical grievances influenced his thinking in a way that never permitted him to free himself from his preoccupation with building a powerful nation in the family of nations'. What we need to understand, however, is that China held a subjective conceptual understanding of great power and responsibility claims that were distinct from the other great powers in international society.

Much of the Chinese experience had been dedicated to recovering the position of the oppressed and this in itself is highly revealing. Even in its early years, the PRC felt that it was necessary to establish a vision of itself and what it could contribute to the world. It brings to light the fact that China held a self-conception that was so deeply embedded that it thought appropriate to espouse such a vision. This derived from a sense that China was 'special' and 'different', and its duty was put forth in a language of solidarity with the disadvantaged peoples of the world. As a Chinese scholar observed, Mao's aspiration was 'for the Chinese nation to play a role appropriate to its history and historical achievement' (Jia Qingguo, 2011, interview). Emerging from its identity as a revolutionary great power with revisionist goals, responsibility was thus framed in terms of injecting a more explicit normative agenda in what it perceived to be an unjust international order.

Table 1. Unpacking the politics of great power responsibility in Nationalist and Maoist China.

\begin{tabular}{|l|l|l|}
\hline & Nationalist China & Maoist China \\
\hline $\begin{array}{l}\text { Location } \\
\text { Self-claimed }\end{array}$ & & \\
\hline
\end{tabular}




\begin{tabular}{|c|c|c|}
\hline $\begin{array}{l}\text { Social } \\
\text { ascription }\end{array}$ & $\begin{array}{l}\text { Despite material weakness, self- } \\
\text { perception as a great power with } \\
\text { special managerial responsibilities } \\
\text { Ascribed primarily by the US but } \\
\text { resisted by other great power peers }\end{array}$ & $\begin{array}{l}\text { Self-perception as a great power } \\
\text { with special and explicitly } \\
\text { normative responsibilities } \\
\text { Ascribed by developing nations } \\
\text { and key American allies, but } \\
\text { deeply contested by the US }\end{array}$ \\
\hline Object & $\begin{array}{l}\text { Responsibility to great power } \\
\text { peers and the rest of international } \\
\text { society, and directed particularly } \\
\text { to Asia }\end{array}$ & $\begin{array}{l}\text { Responsibility directed } \\
\text { specifically to the Third World } \\
\text { and to struggle against the } \\
\text { superpowers }\end{array}$ \\
\hline Nature & $\begin{array}{l}\text { Establish and maintain a post-war } \\
\text { international order and } \\
\text { organisation that institutionalises } \\
\text { great power management; Seek } \\
\text { equality, fairness and justice } \\
\text { through international law }\end{array}$ & $\begin{array}{l}\text { Oppose hegemonism and } \\
\text { imperialism; Overthrow and } \\
\text { transform the existing } \\
\text { international order; Seek equality, } \\
\text { fairness and justice through } \\
\text { revolution }\end{array}$ \\
\hline Rationale & $\begin{array}{l}\text { Responsible agency justified } \\
\text { through an appreciation of } \\
\text { Chinese culture and civilisation; } \\
\text { Elevate and legitimise China's } \\
\text { international standing; Restore a } \\
\text { China-centred order in post-war } \\
\text { Asia; }\end{array}$ & $\begin{array}{l}\text { Identity as a revolutionary great } \\
\text { power with revisionist aims; } \\
\text { Solidarity with the oppressed and } \\
\text { disadvantaged; Restore China's } \\
\text { rightful position in international } \\
\text { society }\end{array}$ \\
\hline
\end{tabular}

\section{Conclusion}


The language of great power responsibility is undoubtedly frequently invoked in international politics. Although intermittently upheld, the practice of great power responsibility is arguably also a prominent feature in international relations. Much less attention, however, has been paid to the politics of great power responsibility and how the concept of great power responsibility should be understood. By arguing for the need to unpack great power responsibility as a socially constructed and negotiated concept, this article has sought to advance the conceptual discussion on great power responsibility. Ideas of great power responsibility and 'the social' relate not only to what is shared and agreed, but what might be negotiated, resisted and contested. In this regard, notions of great power responsibility are the product of, and remain subject to, processes of construction, intense deliberations and negotiations, resistance and reconstruction. Rather than only focusing on the intersubjective, then, we need to examine the politics of great power responsibility. The established typology on the location, object, nature and rationale of responsibility is a way to map out these dynamics in a clearer fashion.

This article has also provided an account of Chinese historical agency through the lens of the typology. It has uncovered the processes of both conflict and concordance that have shaped Chinese engagements with the question of great power responsibility at two critical international order-building junctures. As Table 1 summarises, there have been continuities and discontinuities across the two periods. Continuities may be observed more 
broadly in the location and rationale of China's responsibility. China has persistently conceived itself as a great power with special responsibilities extending beyond the self. It has striven to be recognised and accepted as a member of the great power club, with the US as the most important actor in either supporting or contesting China's great power membership. In addition, the Chinese leadership has always rationalised and justified its responsibilities in connection with China's history, culture and identity. The pursuit of centrality, and of restoring China's rightful position in international society, has been, and remains, a key driving factor in China's foreign policy orientation. Discontinuities, however, lie in the object and nature of China's responsibility. While the domestic-international nexus remains important to answering the question 'responsibility to whom', Nationalist China directed its responsibilities more in keeping with dominant Western understandings. Maoist China, on the other hand, projected responsibilities toward the Third World. What has nevertheless emerged from the discussion above is that there has always been an orderbuilding aspect within China's subjective conceptions of self, role and responsibility. Throughout its history, China has perceived for itself a managerial role in the construction of international order and has been explicitly concerned with questions of great power responsibility. However, in recognising the complexity of the concept, this article has demonstrated that whilst the discourse of great power responsibility has been a constant feature in its foreign policy, the manner in which China has interpreted the content and nature of its responsibilities remains in constant negotiation. 
${ }^{1}$ A notable exception is Bukovansky et al. (2012).

${ }^{2}$ Although presented as distinct analytical categories for clarity purposes, there are clearly overlaps and connections across the categories.

${ }^{3}$ Parts of this section draw from Loke (2013).

${ }^{4}$ Admittedly the constraints of the Cold War that soon followed and Communist victory in China made it necessary to downplay the importance of Nationalist China's wartime role. A reassessment in recent years, with greater credit given to Chiang's role in the War of Resistance against Japan, is a welcome development. For notable examples, see Liu (1996), Mitter (2013) and Van de Ven, Lary and MacKinnon (2015).

${ }^{5}$ The Dumbarton Oaks conference was split into two phases as a result of Soviet insistence, with the AngloAmerican delegations meeting the Soviets from 21 August to 28 September 1944 and the Chinese from 29 September to 7 October. China submitted its proposal on 23 August, two days after the first phase had started but before its own formal participation in the second phase. China's proposal can be found in FRUS (1944: 718-728).

${ }^{6}$ China's attitude towards the UN nevertheless underwent changes over the years, particularly in the mid-1960s when it embraced a more radical foreign policy.

${ }^{7}$ In June 1950, the PRC accused the US of armed aggression against China's territory, Taiwan and the Penghu Islands, for the purpose of preventing the liberation of Taiwan by the PRC. The PRC charged that US actions constituted a gross violation of the UN Charter. In response, the PRC was invited to sit with the Security Council in discussions of this matter. $\mathrm{Wu}$ headed the delegation and became the first representative from the PRC to address the Council.

\section{References}

Alderson K and Hurrell A (eds) (2000) Hedley Bull on International Society. Basingstoke, Hampshire: Macmillan Press Ltd.

Breslin S (2010) China's emerging global role: Dissatisfied responsible great power. Politics 30(S1): 52-62.

Brown C (2004) Do great powers have great responsibilities? Great powers and moral agency. Global Society 18(1): 5-19.

Bukovansky M et al. (2012) Special Responsibilities: Global Problems and American Power. Cambridge: Cambridge University Press.

Bull H (1964) The Atlantic alliance and arms control. Council on Foreign Relations, Atlantic Policy Studies, Steering Committee Meeting, 28-29 April. Hedley Bull Papers, Special Collections (Modern Political Papers), University of Oxford. Box 3: Strategic Studies, File II: Arms Control (General).

Bull H (1966) The Grotian conception of international society. In: Butterfield H and Wight M (eds) Diplomatic Investigations: Essays in the Theory of International Politics. Cambridge, MA: Harvard University Press, pp. 51-73. 
Bull H (1968) Afro-Asian states and the Western international order: A statement of the problem. Department of International Relations, Research School of Pacific Studies, The Australian National University. Hedley Bull Papers, Special Collections (Modern Political Papers), University of Oxford. Box 2: International Relations Theory, File IX: Rise of the Third World/Revolt against Western Dominance.

Bull H (1973) The new strategic balance in Asia and the Pacific. Address to the twenty fifth Defence Research Board Symposium, Ottawa, 13 November. Hedley Bull Papers, Special Collections (Modern Political Papers), University of Oxford. Box 6: Australia.

Bull H (1977) The Anarchical Society: A Study of Order in World Politics. Hampshire: Palgrave, $3^{\text {rd }}$ edition.

Bull H (1983) Justice in international relations: The 1983 Hagey Lectures. In: Alderson K and Hurrell A (eds) (2000) Hedley Bull on International Society. London: Macmillan Press Ltd, pp. 206- 245.

Buzan B (2004a) From International to World Society? English School Theory and the Social Structure of Globalisation. Cambridge: Cambridge University Press.

Buzan B (2004b) The United States and the Great Powers: World Politics in the TwentyFirst Century. Cambridge: Polity Press.

Cane P (2002) Responsibility in Law and Morality. Oxford and Portland, OR: Hart Publishing.

Chen J (2001) Mao's China and the Cold War. Chapel Hill, NC: The University of North Carolina Press.

Chen Z (2005) Nationalism, internationalism and Chinese foreign policy. Journal of Contemporary China 14(42): 35-53.

Chiang KS (1940) The international role of the republic", A 'double tenth' message to the army and the people, 10 October. In: Chiang KS (1943) Resistance and Reconstruction: Messages During China's Six Years of War, 1937-1943. New York, NY: Harper \& Brothers Publishers, pp. 206-214.

Chiang KS (1942) From equality to ideal unity. Address at the closing ceremony of the Third People's Political Council, 31 October. In: Chiang KS (1943) Resistance and Reconstruction: 
Messages During China's Six Years of War, 1937-1943. New York, NY: Harper \& Brothers Publishers, pp. 307-311.

Chiang KS (1947) China's Destiny. New York, NY: The Macmillan Company.

Chou EL (1956) On present international situation, China's foreign policy, and the liberation of Taiwan. Speech delivered at the third session of the First National People's Congress, 28 June. Peking: Foreign Language Press.

Clark I (2009) Towards an English School theory of hegemony. European Journal of International Relations 15(2): 203-228.

Clark I and Reus-Smit C (2013) Liberal internationalism, the practice of special responsibilities and evolving politics of the Security Council. International Politics 50(1): $38-56$.

Claude IL Jr (1986) The common defense and great-power responsibilities. Political Science Quarterly 101(5): 719-732.

Craft SG (2004) V.K. Wellington Koo and the Emergence of Modern China. Lexington, KY: The University Press of Kentucky.

Dallek R (1979) Franklin D. Roosevelt and American Foreign Policy, 1932-1945. New York, NY: Oxford University Press.

Davis F (1943) Roosevelt's world blueprint. Saturday Evening Post 215(41), 10 April, pp. 20-21, 109-110.

De Nevers R (2007) Imposing international norms: Great powers and norm enforcement. International Studies Review 9(1): 53-80.

Dunne T (2008) The English School. In: Reus-Smit C and Snidal D (eds) The Oxford Handbook of International Relations. Oxford: Oxford University Press, pp. 267-285.

Erskine T (2003) Introduction: Making sense of 'responsibility' in international relationsKey questions and concepts. In: Erskine T (ed) Can Institutions Have Responsibilities? Collective Moral Agency and International Relations. New York, NY: Palgrave Macmillan, pp. 1-16. 
Finnemore M (2001) Exporting the English School?, Review of International Studies 27(3): 509-513.

Foot R (1995) The Practice of Power: U.S. Relations with China since 1949. Oxford: Oxford University Press.

Fordham BO and Asal V (2007) Billard balls or snowflakes? Major power prestige and the international diffusion of institutions and practices. International Studies Quarterly 51(1): $31-52$.

Frost M (2003) Constitutive theory and moral accountability: Individuals, institutions, and dispersed practices. In: Erskine T (ed) Can Institutions Have Responsibilities? Collective Moral Agency and International Relations. New York, NY: Palgrave Macmillan, pp. 84-99.

FRUS (1944) Foreign Relations of the United States: Diplomatic Papers 1944, General, Vol. I. Washington, DC: Department of State (published 1966).

Harries O (2005) Power, morality, and foreign policy. Orbis 49(4): 599-612.

Hilderbrand RC (1990) Dumbarton Oaks: The Origins of the United Nations and the Search for Postwar Security. Chapel Hill, NC: The University of North Carolina Press.

Hoover J (2012) Reconstructing responsibility and moral agency in world politics. International Theory 4(2): 233-268.

Hopf T (1998) The promise of constructivism in International Relations theory. International Security 23(1): 171-200.

Hull C (1948) The Memoirs of Cordell Hull: Volume Two. London: Hodder \& Stoughton.

Hurrell A (2007) On Global Order: Power, Values, and the Constitution of International Society. Oxford: Oxford University Press.

Ikenberry GJ (2011) Liberal Leviathan: The Origins, Crisis, and Transformation of the American World Order. Princeton, NJ: Princeton University Press.

Jackson RH (2004) Sovereignty as a doctrine of moderation. In: Nolan CJ (ed) Power and Responsibility in World Affairs: Reformation versus Transformation. Westport, CT: Praeger Publishers, pp. 57-76. 
Kaufman VS (2000) 'Chirep': The Anglo-American dispute over Chinese representation in the United Nations, 1950-71. The English Historical Review 115(461): 354-377.

Kim SS (1979). China, the United Nations, and World Order. Princeton, NJ: Princeton University Press.

Kimball WF (2008) The sheriffs: FDR's postwar world. In: Wollner DB, Kimball WF and Reynolds D (eds) FDR's World: War, Peace, and Legacies. New York, NY: Palgrave Macmillan, pp. 91-121.

Liu X (1996) A Partnership for Disorder: China, the United States, and their Policies for the Postwar Disposition of the Japanese Empire. Cambridge: Cambridge University Press.

Loke B (2013) Conceptualising the role and responsibility of great power: China's participation in negotiations toward a post-second world war order. Diplomacy and Statecraft 24(2): 209-226.

Mearsheimer JJ (2001) The Tragedy of Great Power Politics. New York, NY: W. W. Norton and Company.

Mitter R (2013) China's War with Japan, 1937-1945: The Struggle for Survival. London: Allen Lane.

Morgenthau HJ (1973) Politics among Nations: The Struggle for Power and Peace. New York: Alfred A. Knopf, 5th edition.

Morris J (2013) From 'Peace by Dictation' to international organisation: Great power responsibility and the creation of the United Nations. The International History Review 35(3): 511-533.

Nolan CJ (2004) The evolution of great power rights and responsibilities. In: Nolan CJ (ed) Power and Responsibility in World Affairs: Reformation versus Transformation. Westport, CT: Praeger Publishers, pp. 15-37.

Peking Review (1971) Speech by Chiao Kuan-hua, 15 November 1971. 14(47): 5-9.

Qin Y (2010) International society as a process: Institutions, identities, and China's peaceful rise. The Chinese Journal of International Politics 3(2): 129-153.

Range W (1959) Franklin D. Roosevelt's World Order. Athens: University of Georgia Press. 
Rosenthal JH (1991) Righteous Realists: Political Realism, Responsible Power, and American Culture in the Nuclear Age. Baton Rouge: Louisiana State University Press.

Schweller RL (1994) Bandwagoning for profit: Bringing the revisionist state back in", International Security 19(1): 72-107.

Schweller RL and Pu X (2011) After unipolarity: China's visions of international order in an era of U.S. decline. International Security 36(1): 41-72.

Simpson G (2004) Great Powers and Outlaw States: Unequal Sovereigns in the International Legal Order. Cambridge: Cambridge University Press.

Smiley M (1992) Moral Responsibility and the Boundaries of Community: Power and Accountability from a Pragmatic Point of View. Chicago, IL: The University of Chicago Press.

United Nations Security Council (UN SC) (1971) Official Records. 1599 th Meeting, 23 November (S/PV.1599). Available at http://daccess-ddsny.un.org/doc/UNDOC/GEN/NL7/100/54/PDF/NL710054.pdf?OpenElement (accessed 26 April 2015).

Van de Ven H (2015) The 1952 Treaty of Peace between China and Japan’ In: Van de Ven H, Lary D and MacKinnon SR (eds) Negotiating China's Destiny in World War II. Stanford, CA: Stanford University Press, pp. 220-238.

Van de Ven H, Lary D and MacKinnon SR (eds) (2015) Negotiating China's Destiny in World War II. Stanford, CA: Stanford University Press.

Van Ness P (1993) China as a Third World state: Foreign policy and official national identity. In: Dittmer L and Kim SS (eds) China's Quest for National Identity. Ithaca, New York: Cornell University Press, pp. 194-214.

Vincent RJ (1990) Order in international politics. In: Miller JDB and Vincent RJ (eds) Order and Violence: Hedley Bull and International Relations. Oxford: Oxford University Press, pp. $38-64$.

Waltz KN (1979) Theory of International Politics. New York, NY: Random House. 
Wendt A (1999) Social Theory of International Politics. Cambridge: Cambridge University Press.

Weng BS (1966) Communist China's changing attitudes toward the United Nations. International Organization 20(4): 678-694.

Wheeler NJ (1992) Pluralist or solidarist conceptions of international society: Bull and Vincent on humanitarian intervention. Millennium 21(3): 463-487.

Wight M (1978) Power Politics. Leicester: Leicester University Press.

Wu HC (1950) Speech at the United Nations Security Council, 28 November. In: China Accuses! Speeches of the Special Representative of the Central People's Government of the People's Republic of China at the United Nations (1951). Peking: Foreign Languages Press.

Xu G (2005) China and the Great War: China's Pursuit of a New National Identity and Internationalization. Cambridge: Cambridge University Press.

Zhang Y (2001) System, empire and state in Chinese international relations. Review of International Studies 27 (5): 43-63.

Zimmern A (1939) The League of Nations and the Rule of Law, 1918-1935. London: MacMillan and Co., Ltd.

Zoellick RB (2005) Whither China: From membership to responsibility? U.S. Department of State Archive. Available at: http://2001-2009.state.gov/s/d/former/zoellick/rem/53682.htm (accessed 24 April 2015). 